Research Article

\title{
Helminth Infection in Pregnancy: Effect on Serum Albumin Level and Pregnancy outcome
}

\author{
Infeksi Cacing pada Kehamilan: Pengaruh Terhadap \\ Kadar Albumin dan Luaran Kehamilan
}

\author{
Steven Ridwan', Sitti Wahyuni' ${ }^{2}$, Maisuri T Chalid ${ }^{1}$ \\ ${ }^{1}$ Department of Obstetrics and Gynecology \\ ${ }^{2}$ Department of Parasitology \\ Faculty of Medicine University of Hasanuddin/ \\ Dr. Wahidin Sudirohusodo Hospital \\ Makassar
}

\begin{abstract}
Objective: To determine the prevalence of helminth infection in pregnant women and its effect on albumin levels and pregnancy outcome.

Method: A prospective cohort study was conducted on third trimester pregnant women presenting for antenatal care in several hospitals in Makassar. Information on subject demography was recorded using short questionnaire. Stool samples were collected to determine the presence of helminth infection. Albumin levels were measured from maternal blood and cord-blood. Outcome of pregnancy was assessed upon delivery.

Result: The prevalence of helminth infection in our subjects was $22.8 \%$. Among 21 infected women, 17 were infected with Ascaris lumbricoides (80.9\%), one with Trichuris trichiura and three with both Ascaris and Trichuris. The mean Ascaris lumbricoides intensity was $1769.3 \mathrm{epg}$ (Range = 24-11.688 epg). Helminth infections have no effect on either maternal or neonatal albumin levels $(\mathrm{p}=0.748$ and $p=0.480$, respectively). Although it was not found to be significant ( $>0.05)$, helminth infection seems to affect gestational age (OR 2.06, 95\% CI 1.48-2.86) and birth weight (OR 2.18, 95\% CI 1.52-3.14). Neonatal albumin level and pregnancy outcome were not affected by maternal albumin level.

Conclusion: Helminth infection seems to affect pregnancy outcome in pregnant women in Makassar, but not through influence of albumin. Factors other than albumin level may responsible for such condition.

[Indones J Obstet Gynecol 2015; 1: 19-25]

Keywords: albumin, birth length, birth weight, gestational age, helminth infection
\end{abstract}

\begin{abstract}
Abstrak
Tujuan: Untuk menentukan prevalensi infeksi cacing pada ibu hamil dan pengaruhnya terhadap kadar albumin dan luaran kehamilan.

Metode: Penelitian kohort prospektif dilakukan pada ibu hamil trimester tiga yang menjalani pemeriksaan antenatal di beberapa rumah sakit di Makassar. Informasi demografis subjek dicatat dengan menggunakan kuesioner singkat. Sampel tinja dikumpulkan untuk menentukan adanya infeksi cacing. Kadar albumin diukur dari darah ibu hamil dan darah tali pusat bayi. Luaran kehamilan dinilai segera setelah persalinan.
\end{abstract}

Hasil: Prevalensi infeksi cacing pada wanita hamil adalah 22,8\%. Di antara 21 ibu yang terinfeksi, 17 diantaranya terinfeksi Ascaris lumbricoides $(80,9 \%)$, satu ibu terinfeksi Trichuris trichiura, dan tiga dengan infeksi campuran Ascaris dan Trichuris. Rerata intensitas infeksi Ascaris lumbricoides adalah 1769,3 epg (Rentang = 24-11,688 epg). Meskipun pengaruhnya tidak bermakna secara statistik $(p>0,05)$, infeksi cacing ditemukan memiliki pengaruh terhadap masa gestasi (OR 2,06; IK 95\% 1,48-2,86) dan berat badan lahir (OR 2,18; IK 95\% 1,52-3,14). Tidak ditemukan pengaruh infeksi cacing terhadap kadar albumin ibu $(p=0,748)$ dan bayi $(p=0,480)$. Kadar albumin ibu juga tidak berpengaruh terhadap kadar albumin bayi dan luaran kehamilan.

Kesimpulan: Infeksi cacing ditemukan mempengaruhi masa gestasi dan luaran kehamilan, namun tidak melalui kadar albumin. Faktor selain albumin mungkin bertanggung jawab atas terjadinya keadaan tersebut.

[Maj Obstet Ginekol Indones 2015; 1: 19-25]

Kata kunci: albumin, berat lahir, infeksi cacing, panjang lahir, usia kehamilan

Correspondence: Steven Rodwan. Jln. Tinumbu 304, Makassar. Mobile: 081354858680, Email: stvmrdwan@gmail.com

\section{INTRODUCTION}

Ascaris lumbricoides, hookworms, and Trichuris trichiura are the most common intestinal helminths encountered throughout the tropical and subtropical countries. More than 1 billion people are infected with at least one helminth species, and more than 4 billion are at risk of infection. ${ }^{1,2} \mathrm{Al}$ though low worm burden often go unnoticed, about 450 million people suffer from significant morbidity caused by helminths. ${ }^{3,4}$

Beside children and the elderly, pregnant women is a group with particular susceptibility and suffer the majority of the effect of helminth infection. It is estimated about 44.3 million of 124.3 million pregnant women in developing countries are infected with helminth. ${ }^{4}$ Among them, about $10 \%$ has severe infection leading to preterm labor and low birth weight. . $^{-7}$ 
Intestinal helminthiasis is commonly associated with blood loss and decreased supply of nutrients needed for erythropoiesis. ${ }^{7}$ Beside that, two studies India and Kashmir discovered the presence of protein deficiency in helminth-infected subjects. ${ }^{8,9}$ One important protein for human is albumin. ${ }^{10} \mathrm{Se}$ rum albumin is produced by the liver, dissolved in plasma and is the most abundant blood protein in mammals. Albumin is essential for the maintenance of oncotic pressure needed for proper distribution of bodily fluids between blood vessels and extravascular tissues. Without albumin, the high pressure in blood vessels would force intravascular fluids out into the tissues. Albumin also acts as a plasma carrier by non-specifically binding several hydrophobic steroid hormones and as a transport protein for hemin and fatty acids. ${ }^{10,11}$ However, it is still disputable whether helminth infection affects albumin levels in the human body.

According to the 2005 National Socio-economic Survey (Survei Sosial Ekonomi Nasional/SUSENAS) ${ }^{12}$ and the Indonesian Health Profile published by the Indonesian Ministry of Health in 200913, low birth weight and infant mortality rate in Indonesia were $38.85 \%$ and 34 per 1000 livebirths, respectively. One study conducted in Central Java found that the prevalence of helminth infection in pregnant women was $69.7 \%{ }^{14}$ It is still disputed whether helminth infection, through changes in albumin, play an important role in causing pregnancy morbidity or adverse pregnancy outcome in Indonesia. We aim to investigate the effect of helminth infection on albumin level and pregnancy outcome in this study.

\section{METHODS}

This study was an observational study using prospective cohort approach. Third trimester pregnant women residing in Makassar and presenting for antenatal care in Sitti Fatimah, Pertiwi, Labuang Baji and Haji Hospitals between September and December 2012 were inquired for participation. After informed consent and agreement of participation were obtained, information regarding age, parity, education and occupation was collected using short questionnaire. This study was reviewed by the Hasanuddin University Ethical Committee for Human Research.
Stool samples were collected and examined using Kato Katz technique for presence of helminth and its intensity. Soon after delivery, $3 \mathrm{ml}$ venous blood was obtained from the mother and $3 \mathrm{ml}$ cord blood was obtained from the placenta. After separation from blood cells, the sera were processed in Dr. Wahidin Sudirohusodo hospital for albumin level measurement. The serum albumin was classified as low when it was found to be lower than $3.5 \mathrm{~g} / \mathrm{dl}^{10}$

After delivery, gestational age, birth weight, and length were recorded. Gestational age was classified as preterm when the duration of gestation was shorter than 37 weeks. Baby weight and length were classified as abnormal if the weight was less than 2500 gram and the length less than $47 \mathrm{~cm}^{15}$ To analyze the association between helminth infection and variables of interest, we randomly selected 19 samples that were not helminth-infected, and 20 samples from the helminth-infected group for serum albumin level examination.

Data was analyzed using SPSS 17 trial program. The association between helminth infection and maternal albumin level, neonatal albumin level, and other variables of interest was calculated using fisher's exact test. The association was regarded as significant if the $\mathrm{p}$ value $<0.05$.

\section{RESULTS}

In our sample, 21 pregnant women $(22.83 \%)$ in the third trimester of the 92 women who provided stool samples were shown to have intestinal helminth infection. Among the infected women, 20 were infected by only Ascaris lumbricoides, one by only Trichuris trichiura, and three by both Ascaris and Trichuris. No hookworm was detected in the stool samples. One of 20 Ascaris infected mother showed a very high intensity of infection $(21,840$ epg). Therefore, her data was excluded when calculating the mean helminth intensity. The intensity of Ascaris infection among the remaining samples ranged from 24 to 11,688 epg; with mean intensity of 1769.3 epg. As shown in Table 1, mother's age ranged between 17-38 years old and multigravidity was found in $56.5 \%$ of our subjects.

Pregnancy outcome was measured soon after delivery. The proportion of mothers who delivered 
Table 1. Subject Characteristics and Pregnancy Outcome

\begin{tabular}{|c|c|c|c|}
\hline Variable & $n=92(\%)$ & Range & Mean (SD) \\
\hline \multicolumn{4}{|l|}{ Subject Characteristics } \\
\hline \multicolumn{4}{|l|}{ Helminth infection } \\
\hline Absent & $71(77.17)$ & 24-11,688 epg & $1769.3 \mathrm{epg}$ \\
\hline Present & $21(22.83)$ & & \\
\hline \multicolumn{4}{|l|}{ Maternal albumin (gr/dl)* } \\
\hline$<3.5$ & $16(41 \%)$ & $2.99-5.31$ & $3.78 \mp 0.67$ \\
\hline$\geq 3.5$ & $23(59 \%)$ & & \\
\hline \multicolumn{4}{|l|}{ Mother's age (years old) } \\
\hline$<25$ & $31(33.7 \%)$ & $17-38$ & $26.4 \mp 4.8$ \\
\hline$\geq 25$ & $61(66.3 \%)$ & & \\
\hline \multicolumn{4}{|l|}{ Gravidity } \\
\hline Primigravida & $40(43.5)$ & $1-7$ & $1.56 \mp 0.49$ \\
\hline Multigravida & $52(56.5)$ & & \\
\hline \multicolumn{4}{|l|}{ Pregnancy outcome } \\
\hline \multicolumn{4}{|l|}{ Gestational age (weeks) } \\
\hline$<37$ & $2(2.2 \%)$ & $33-41$ & $38.71 \mp 1.25$ \\
\hline$\geq 37$ & $90(97.8 \%)$ & & \\
\hline \multicolumn{4}{|c|}{ Neonates birth weight (gram) } \\
\hline$<2500$ & $5(5.4 \%)$ & $2200-3800$ & $2969 \mp 279.8$ \\
\hline$\geq 2500$ & $87(94.6 \%)$ & & \\
\hline \multicolumn{4}{|l|}{ Neonates birth length $(\mathrm{cm})$} \\
\hline$<48$ & $29(31.5 \%)$ & $42-53$ & $48.23 \mp 1.44 \mathrm{~cm}$ \\
\hline$\geq 48$ & $63(68.5 \%)$ & & \\
\hline \multicolumn{4}{|l|}{ Neonates albumin $(\mathrm{g} / \mathrm{dl})^{*}$} \\
\hline$<3.5$ & $11(28.2 \%)$ & $1.9-7.15$ & $4.00 \mp 0.96 \mathrm{~g} / \mathrm{dl}$ \\
\hline$\geq 3.5$ & $28(71.8 \%)$ & & \\
\hline
\end{tabular}

* available sera $(n=39)$

at gestational age $<37$ week was $2.2 \%$. Approximately $5.4 \%$ of the babies were born with low birth weight and $31.5 \%$ had a shorter birth length. From the 39 available cord blood samples, 11 samples had albumin concentration $<3.5 \mathrm{gr} / \mathrm{dl}$.

As shown in Table 2, helminth infection has no effect on either maternal or neonatal albumin le- vels. Interestingly, although the association was not found to be statistically significant, our study discovered a tendency for helminth infection to increase the risk for preterm birth and low birth weight up to two-fold. No association was identified between maternal albumin levels and neonatal albumin, as well as pregnancy outcomes (Table 3). 
Table 2. Effect of Helminth Infection on Albumin Level and Pregnancy Outcome

\begin{tabular}{|c|c|c|c|c|c|}
\hline \multirow{2}{*}{\multicolumn{2}{|c|}{ Outcome of Interest }} & \multicolumn{2}{|c|}{ Helminth infection } & \multirow{2}{*}{ OR (95\%CI) } & \multirow{2}{*}{$p$} \\
\hline & & Present $n=20(\%)$ & Absent n=19 (\%) & & \\
\hline \multicolumn{6}{|c|}{ Maternal albumin (g/dl) } \\
\hline Low & $<3.5$ & $9(45.0)$ & $7(36.8)$ & $1.40(0.39-5.06)$ & 0.748 \\
\hline Normal & $\geq 3.5$ & $11(55.0)$ & $12(63.2)$ & & \\
\hline \multicolumn{6}{|c|}{ Neonatal albumin $(\mathrm{g} / \mathrm{dl})$} \\
\hline Low & $<3.5$ & $7(35.0)$ & $4(21.1)$ & $2.02(0.48-8.48)$ & 0.48 \\
\hline Normal & $\geq 3.5$ & $13(65.0)$ & $15(78.9)$ & & \\
\hline \multicolumn{6}{|c|}{ Gestational age (weeks) } \\
\hline Preterm & $<37$ & $2(10.0)$ & $0(0)$ & $2.06(1.48-2.86)$ & 0.487 \\
\hline Term & $\geq 37$ & $18(90.0)$ & $19(100)$ & & \\
\hline \multicolumn{6}{|l|}{ Birth weight (gr) } \\
\hline Low & $<2500$ & $4(20.0)$ & $0(0)$ & $2.18(1.52-3.14)$ & 0.106 \\
\hline Normal & $\geq 2500$ & $16(80.0)$ & $19(100)$ & & \\
\hline \multicolumn{6}{|c|}{ Birth length (cm) } \\
\hline Short & $<48$ & $10(50)$ & $5(26.3)$ & $2.80(0.73-10.75)$ & 0.191 \\
\hline Normal & $\geq 48$ & $10(50)$ & $14(73.7)$ & & \\
\hline
\end{tabular}

Table 3. Effect of Maternal Albumin Level on Neonatal Albumin Level and Pregnancy Outcome

\begin{tabular}{|c|c|c|c|c|c|}
\hline \multirow{2}{*}{\multicolumn{2}{|c|}{ Outcome of Interest }} & \multicolumn{2}{|c|}{ Maternal albumin (g/dl) } & \multirow{2}{*}{ OR (95\%CI) } & \multirow{2}{*}{$p$} \\
\hline & & Low $(<3.5) \mathrm{n}=16(\%)$ & Normal $(\geq 3.5) n=23(\%)$ & & \\
\hline \multicolumn{6}{|c|}{ Neonatal albumin $(\mathrm{g} / \mathrm{dl})$} \\
\hline Low & $<3.5$ & $6(37.5)$ & 5 (21.7) & $2.16(0.52-8.90)$ & 0.307 \\
\hline Normal & $\geq 3.5$ & $10(62.5)$ & $18(78.3)$ & & \\
\hline \multicolumn{6}{|c|}{ Gestational age (weeks) } \\
\hline Preterm & $<37$ & $1(6.2)$ & $1(4.3)$ & $1.47(0.08-25.32)$ & 1 \\
\hline Term & $\geq 37$ & 15 (93.8) & 22 (95.7) & & \\
\hline \multicolumn{6}{|l|}{ Birth weight (gr) } \\
\hline Low & $<2500$ & $3(18.8)$ & $1(4.3)$ & $5.07(0.47-54.03)$ & 0.286 \\
\hline Normal & $\geq 2500$ & $16(81.2)$ & $22(95.7)$ & & \\
\hline \multicolumn{6}{|c|}{ Birth length (cm) } \\
\hline Short & $<48$ & $4(25)$ & $11(47.8)$ & $0.36(0.09-1.47)$ & 0.192 \\
\hline Normal & $\geq 48$ & $12(75)$ & $12(52.2)$ & & \\
\hline
\end{tabular}




\section{DISCUSSION}

The prevalence of helminth infection may be influenced by several factors; such as study area, lifestyle, sanitation, socioeconomic, educational, water supply and the use of antihelminthics. The prevalence of helminth infection in pregnant women in Makassar, Indonesia in this study was 22.83\%, similar to reports from Kumasi, Ghana ${ }^{7}$ and Enugu, Nigeria. ${ }^{16}$ A higher prevalence was reported in Central Java, reaching as high as $69.7 \%,{ }^{14}$ and studies done in tropical countries like Uganda $(68 \%)^{17}$, Venezuela $(73.9 \%)^{18}$, Kenya $(76.2 \%)^{19}$, and Ethiopia $(43.5 \%)^{20}$. Our study was carried out in Makassar, the capital city of South Sulawesi province, where people have better sanitation, socioeconomic condition, and education; while the Central Java study ${ }^{14}$ was conducted in a rural area. The studies in Ghana and Nigeria were also conducted in urban areas, explaining the similar results. ${ }^{7,16}$

Ascaris lumbricoides was identified as the most prominent cause of infection in our population, followed by Trichuris trichiura, while none had hookworm infection. This is similar to studies from Venezuela ${ }^{18}$ and Kenya ${ }^{19}$. In Central Java, Trichuris trichiura is the most prominent helminth in the population of pregnant women, followed by Necator americanus and Ascaris lumbricoides. ${ }^{14}$ The difference in species predominance might be due to variation in hygiene practices, temperature, altitude, soil type, and time of screening. The transmission of hookworm, for instance, is reported to be predominant in highland areas as seen in high altitude areas in Enrekang, South Sulawesi ${ }^{21}$, Bali ${ }^{22}$, and Irian Jaya ${ }^{23}$.

Ascaris lumbricoides is the giant roundworm capable of infecting human, growing to a length of up to $35 \mathrm{~cm}$, and living in the small intestine. ${ }^{24}$ This parasite consumes food that has been processed by the human intestine, and disrupts the absorption of nutrition, which eventually leads to gastrointestinal disturbances, decreased appetite, and intestinal mucosa damage. Intestinal mucosa damage, together with pilfering of nutrients, results in protein depletion. Prolonged protein depletion will alter albumin synthesis through decreased mRNA activity and ribosome disaggregation in the hepatocytes, and thus may lead to hypoalbuminemia. ${ }^{25}$ Hypoalbuminemia during pregnancy may lead to decreasing free fatty acid (FFA) transfer via the placenta and decreased intrauterine supply of amino acids. FFA is necessary for fetal brain develop- ment, cell membrane synthesis, and fetal fat deposit. Finally, hypoalbuminemia during pregnancy may cause low birth weight, as well as prematurity. ${ }^{11,25-27}$ Studies done in helminth-infected population reported a significant association between Ascaris infection and hypoalbuminemia $(\mathrm{p}=0.032){ }^{28}$ Hypoalbuminemia was found in $32.6 \%$ of a helminth-infected group in India. ${ }^{8}$ Another study reported that the albumin level in helminth-infected people was lower than in non-infected ones (3.52 vs 4.23 ; $\mathrm{p}=0.001)^{9}{ }^{9}$

In our study population, helminth infection did not affect albumin level for either of mother or newborn. This may be due to the low intensity of helminth infection in our subjects. According to Chaicisemsari et al, infections with egg count above 450 per visual field can cause a significant decrease in serum albumin level. ${ }^{29}$ This means only heavy intensity helminth infection can lead to nutritional disturbance, hypoalbuminemia and abnormal pregnancy outcome.

An interesting finding was observed in one subject. Among 20 pregnant women infected with $A s$ caris lumbricoides, one had a considerably higher Ascaris intensity compared to the majority of our subjects $(21,840$ eggs per gram). The albumin level of the mother and her baby were $3.0 \mathrm{~g} / \mathrm{dl}$ and 1.9 $\mathrm{g} / \mathrm{dl}$, respectively and her pregnancy outcomes were also unfavorable, with low birth weight $(2200$ gr) and preterm birth at 33 weeks. Whether the low level of albumin and poor pregnancy outcome in this mother were caused by helminth infection or by other factors is unclear since we did not carry out further investigations on food intake or renal function. Nevertheless, the coexistence of high intensity Ascaris infection, hypoalbuminemia, low birth weight, and prematurity in this subject should be recognized.

We faced the problem of lack of power due to the limited number of participants in this study. We found that the risks for prematurity and low birth weight are higher in helminth-infected women, twice the risk of those who were not infected. Although our analysis could not reach significance, we believe that helminth infection affects pregnancy outcome in our population, as reported in prior studies.

Studies investigating helminth infection in pregnant women and albumin level is limited, and to our knowledge, this is the first study on the topic in Indonesia. Although we could not prove, except 
from the excluded subject, the effect of helminth infection on albumin level and pregnancy outcome, we believe that if the samples were selected from an area with high helminth infection intensity and with a higher number of participants, a significant association might be identified.

\section{CONCLUSION}

Helminth infection seems to affect pregnancy outcome, specifically gestational age and birth weight, in Makassar and the effect not in line with albumin level. Helminth infection might contribute to the high infant mortality rate in Indonesia, but could not be explained by changes in albumin level. Many factors; including hemoglobin level, the supply of macro and micronutrients, genetics, as well as physiologic and pathologic changes in both mother and fetus during pregnancy; may also hold an important role in this situation. A study to investigate the effect of helminth infection in pregnancy needs to be conducted in an area with high helminth transmission.

\section{ACKNOWLEDGEMENT}

We would like to thank the women and their babies who participated in this study. We would also like to thank Dr. Trika Irianta, Dr. Eddy Tiro, and Dr. Eddy Moeljono for the advice given before and after the study, and also to my colleague Sitti Rahma for her help in participant recruitment.

\section{REFERENCES}

1. de Silva NR, Brooker S, Hotez PJ, et al. Soil-transmitted helminth infections: updating the global picture. Trends Parasitol. 2003; 19(12): 547-51.

2. Bethony J, Brooker S, Albonico M, G et al. Soil-transmitted helminth infections: ascariasis, trichuriasis, and hookworm. Lancet 2006; 367(9521): 1521-32.

3. Bundy DA, Chan MS, Savioli L. Hookworm infection in pregnancy. Trans R Soc Trop Med Hyg 1995; 89(5): 521-2.

4. World Health Organizations. Report of the WHO informal consultation on hookworm infection and anaemia in girls and women. Geneva: World Health Organization; 1996.

5. Fuseini G, Edoh D, Kalifa BG, et al. Parasitic infections and anaemia during pregnancy in the Kassena-Nankana district of Northern Ghana. J Public Health Epidemiol 2010; 2(3): 48-52.
6. Liabsuetrakul T. Epidemiology and the effect of treatment of soil-transmitted helminthiasis in pregnant women in Southern Thailand. Southeast Asian J Trop Med Public Health 2009; 40(2): 211-22.

7. Yatich NJ, Jolly PE, Funkhouser E, et al. The effect of malaria and intestinal helminth coinfection on birth outcomes in Kumasi, Ghana. J Trop Med Hygiene 2010; 82(1): 28-34.

8. Saraya A, Tandon B, Ramachandran K. A study of iron and protein deficiency in hookworm infestation. Indian J Med Res 1970; 9: 1234-43.

9. Lone BA, Ahmad F, Tak H. Impact of helminth parasites on plasma proteins in children of Kashmir. Int J Adv Res Biotechnol 2012; 1: 5-7.

10. Boldt J. Use of albumin: an update. Bri J Anaest 2010; 104(3): 276-84.

11. Polin RA, Fox WW, Abman SH. (eds.) Maternal lipid metabolism and placental transfer of free fatty acids, glycerol, and ketone bodies to the fetus. Amsterdam: Elsevier; 2013.

12. Badan Pusat Statistik. SUSENAS (Survei sosial ekonomi nasional) panel tahun 2005. Jakarta: Badan Pusat Statistik.

13. Soepardi J, Hasnawati S, Sitohang VM, et al. Profil kesehatan Indonesia tahun 2009. In: Hasnawati S, Sitohang VM, Brahim R. (eds.) Jakarta: Kementrian Kesehatan Republik Indonesia.

14. Nurdiati DS, Sumarni S, Suyoko, et al. Impact of intestinal helminth infection on anemia and iron status during pregnancy: a community based study in Indonesia. Southeast Asian J Trop Med Public Health 2001; 32(1): 14-22.

15. Wardlaw T. Low birthweight: country, regional and global estimates. Geneva: The United Nations Children's Fund and World Health Organization; 2004.

16. Belyhun Y, Medhin G, Amberbir A, et al. Prevalence and risk factor for soil-transmitted helminth infection in mothers and their infants in Butajira, Ethiopia: a population based study. BMC Pub Health 2010; 10(21): 1-7.

17. Rodriguez-Morales AJ, Barbella RA, Case C, et al. Intestinal parasitic infections among pregnant women in Venezuela. Inf Dis Obstet Gynecol 2006; 2006: 23125.

18. Van Eijk AM, Lindblade KA, Odhiambo F, et al. Geohelminth infections among pregnant women in rural western Kenya; a cross-sectional study. Plos Neg Trop Dis 2009; 3(1): 1-9.

19. Ndibazza J, Webb EL, Lule S, et al. Associations between maternal helminth and malaria infections in pregnancy and clinical malaria in the offspring: a birth cohort in Entebbe, Uganda. J Infect Dis 2013; 208(12): 2007-16.

20. Ozumba UC, Ozumba NA, Anya S. Helminthiasis in pregnancy in Enugu, Nigeria. J Health Sci 2005; 51(3): 291-3.

21. Wahyuni S. General introduction. In: Wahyuni S. (ed.) Helminth infections, allergic disorders and immune responses: studies in Indonesia. Netherlands: Leiden University; 2006.

22. Bakta IM, Widjana ID, Sutisna P. Some epidemiological aspects of hookworm infection among the rural population of Bali, Indonesia. Southeast Asian J Trop Med Public Health 1993; 24(1): 87-93.

23. Bangs MJ, Purnomo, Andersen EM, et al. Intestinal parasites of humans in a highland community of Irian Jaya, Indonesia. Ann Trop Med Parasitol 1996; 90(1): 49-53.

24. Centers for Disease Control and Prevention. Parasites - Ascariasis. Atlanta: Centers for Disease Control and Prevention; 2010.

25. Nicholson J, Wolmarans M, Park G. The role of albumin in critical illness. Br J Anaesth 2000; 85: 599-610. 
26. Ocviyanti D. (ed.) Fisiologi kehamilan, persalinan dan laktasi. Jakarta: FKUI; 2008.

27. Sayogo S. (ed.) Kebutuhan nutrisi pada kehamilan. Jakarta: FKUI; 2008.
28. Blumenthal DS, Schultz MG. Effects of Ascaris infection of nutritional status in children. Am J Trop Med Hyg 1976; 25(5): 682-90.

29. Chaichisemsari M, Eshratkhah B, Maherisis N, et al. Evaluation of total protein, albumin, globulin and blood urea nitrogen concentrations in gastrointestinal nematodes infected sheep. Global veterinaria 2011; 6(5): 433-7. 